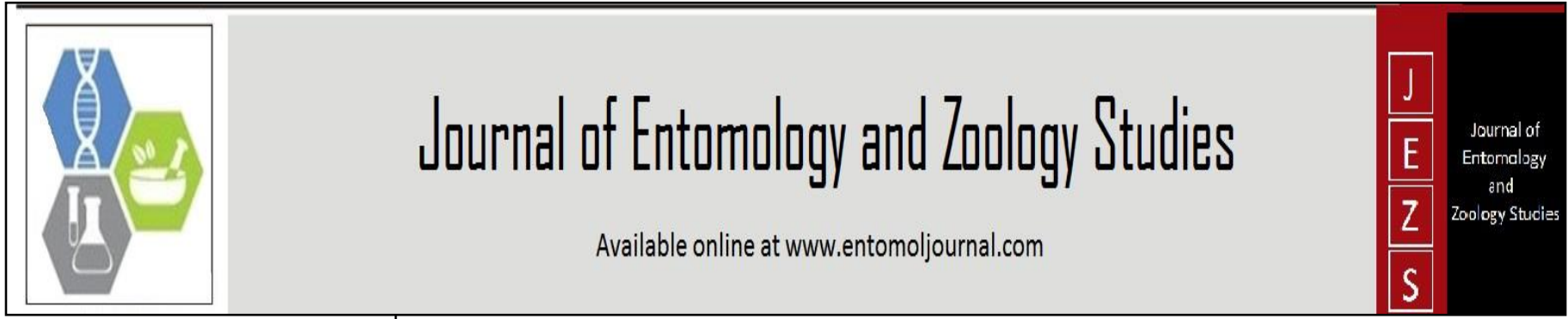

E-ISSN: 2320-7078

P-ISSN: 2349-6800

www.entomoljournal.com

JEZS 2021; 9(3): 58-69

(C) 2021 JEZS

Received: 28-03-2021

Accepted: 30-04-2021

Sedjro Gilles Armel Nago Laboratory of Ecology, Botany and Plant Biology, University of Parakou, Benin

Daniel Sika Chabi-Boni

Laboratory of Ecology, Botany and Plant Biology, University of

Parakou, Benin

Johannes Alikpanou

Laboratory of Ecology, Botany and Plant Biology, University of

Parakou, Benin

Rodéric Roland Singbénou Sagbo Laboratory of Ecology, Botany and Plant Biology, University of Parakou, Benin

Sabirou Moussa Touré

Office National du Bois,

Direction Générale des Eaux,

Forêts et Chasse, Bénin

Armand Kuyéma Natta Laboratory of Ecology, Botany and Plant Biology, University of Parakou, Benin

Guy Apollinaire Mensah Institut National des Recherches Agricoles du Bénin, Cotonou, Bénin

Corresponding Author: Sedjro Gilles Armel Nago Laboratory of Ecology, Botany and Plant Biology, University of Parakou, Benin

\section{Vulnerability and morphometric characteristics of hunting game species in the Lama Forest Reserve (Southern Benin republic)}

\author{
Sedjro Gilles Armel Nago, Daniel Sika Chabi-Boni, Johannes Alikpanou, \\ Rodéric Roland Singbénou Sagbo, Sabirou Moussa Touré, Armand \\ Kuyéma Natta and Guy Apollinaire Mensah
}

DOI: $\underline{\text { https://doi.org/10.22271/j.ento.2021.v9.i3a.8690 }}$

\section{Abstract}

Protected areas play an important role in the sustainable conservation of biodiversity. In southern Benin Republic, the Lama Forest Reserve is a refuge for wildlife. It also generates significant incomes for the local population. However, anthropogenic activities together with uncontrolled hunting are increasingly threatening the sustainability of these resources. The study aims at investigating the hunting activities characteristics and the morphometric traits of hunted species in the Lama Forest Reserve. Snowball method has been used to constitute the sample of field respondents. Descriptive and inference statistics have been carried out to show results and analyze data. The results show that twenty-three species are mainly hunted, more for trade than for subsistence, with a dominance of mammals. It should be noted that hunting activities don't have the same level among hunted games, species and sexes although this is not generally significant statistically.

Keywords: wildlife, bushmeat, morphometric traits, conservation, Semi-deciduous forest

\section{Introduction}

Africa's forest ecosystems are among the richest and most important in terms of diversity and abundance of both plant and animal species ${ }^{[1]}$. In some societies, wildlife is an important source of animal protein ${ }^{[2-5]}$, an essential component of food and income security for rural communities ${ }^{[6-8]}$ and also hunting trophies ${ }^{[9]}$. The impact of anthropogenic pressures on animal species is well documented in tropical forests ${ }^{[10]}$. Game hunting is increasingly causing a reduction in wildlife populations ${ }^{[11-16]}$. The export of bushmeat from rural communities in Africa to Europe makes this market more clandestine and therefore has a negative impact on conservation actions ${ }^{[17]}$. This is exacerbated by the use of sophisticated modern weapons ${ }^{[15}$, ${ }^{18]}$. In the fields, weapons are used to preserve crops, unlike in the forest ${ }^{[19]}$. The most commonly used hunting tools are traps and rifles ${ }^{[19]}$. In this socio-economic context, the challenge of protecting endangered species is to reconcile sustainable conservation while taking into account the realities and needs of populations ${ }^{[20]}$.

In Benin, population growth ${ }^{[21]}$ implies a significant need for meat. Despite its negative impacts, hunting remains an important protein supply activity for communities close to wildlife reserves ${ }^{[22]}$. In the Pendjari Biosphere Reserve, several clandestine circuits have been developed to illegally circulate bushmeat and hunting trophies ${ }^{[23]}$. The Pendjari and W Biosphere Reserves in the northern part of Benin and the Lama Forest Reserve in the Southern part are among the ecosystems where hunting activity is really important in the country. In the first two protected areas, there is open hunting season per year and period when hunting is prohibited. But hunting is carried out all the year round by the populations in Lama Forest Reserve. The people around the Lama Rainforest consider all types of bushmeat edible despite government restrictions on hunting ${ }^{[24]}$. About twenty species are mainly hunted in the Lama Forest Reserve ${ }^{[25]}$. Hunting and the bushmeat trade are then organised informally, with the development of networks between various actors ${ }^{[26]}$. Although the practice/phenomenon cannot be completely banned, there is still an urgent need to limit not only the slaughter rate but also characterize the morphometric traits of the hunted species in order to ensure their 
sustainability. A number of aspects related to hunting and bushmeat have been studied in the Lama Forest Reserve, such as those of Codjia and Assogbadjo ${ }^{[2]}$ and Djagoun et al. ${ }^{[25]}$, but the literature is still to be documented with regard to morphometric measurements and the weight of hunted species. However, the sustainability of natural resources depends on knowledge of resources, resource conservation and rational use by local populations. Thus, the general objective of the study is to investigate the hunting activities characteristics and the morphometric traits of hunted species in the Lama Forest Reserve. Specifically, it involves (1) identifying the species hunted in the Lama Forest Reserve, (2) highlighting the forms and methods of hunting in the Lama Forest Reserve, (3) Collecting morphometric data of sampled species and (4) assessing the impact of hunting on wildlife conservation.

\section{Materials and Methods}

\subsection{Study environment}

The study area is the Lama Forest Reserve, one of the rare relics of dense semi-deciduous forest still perceptible in the southern part of the country. The Lama Forest Reserve is located in the southern part of Benin (Figure 1), about $70 \mathrm{~km}$ from Cotonou. It extends between $6^{\circ} 55^{\prime}$ and $7^{\circ} 00^{\prime}$ north latitude and between $2^{\circ} 04^{\prime}$ and $2^{\circ} 12^{\prime}$ east longitude, over an area of 16,250 ha ${ }^{[27]}$. It straddles the communes of Toffo (9,750 ha) and Zogbodomey (6,500 ha).

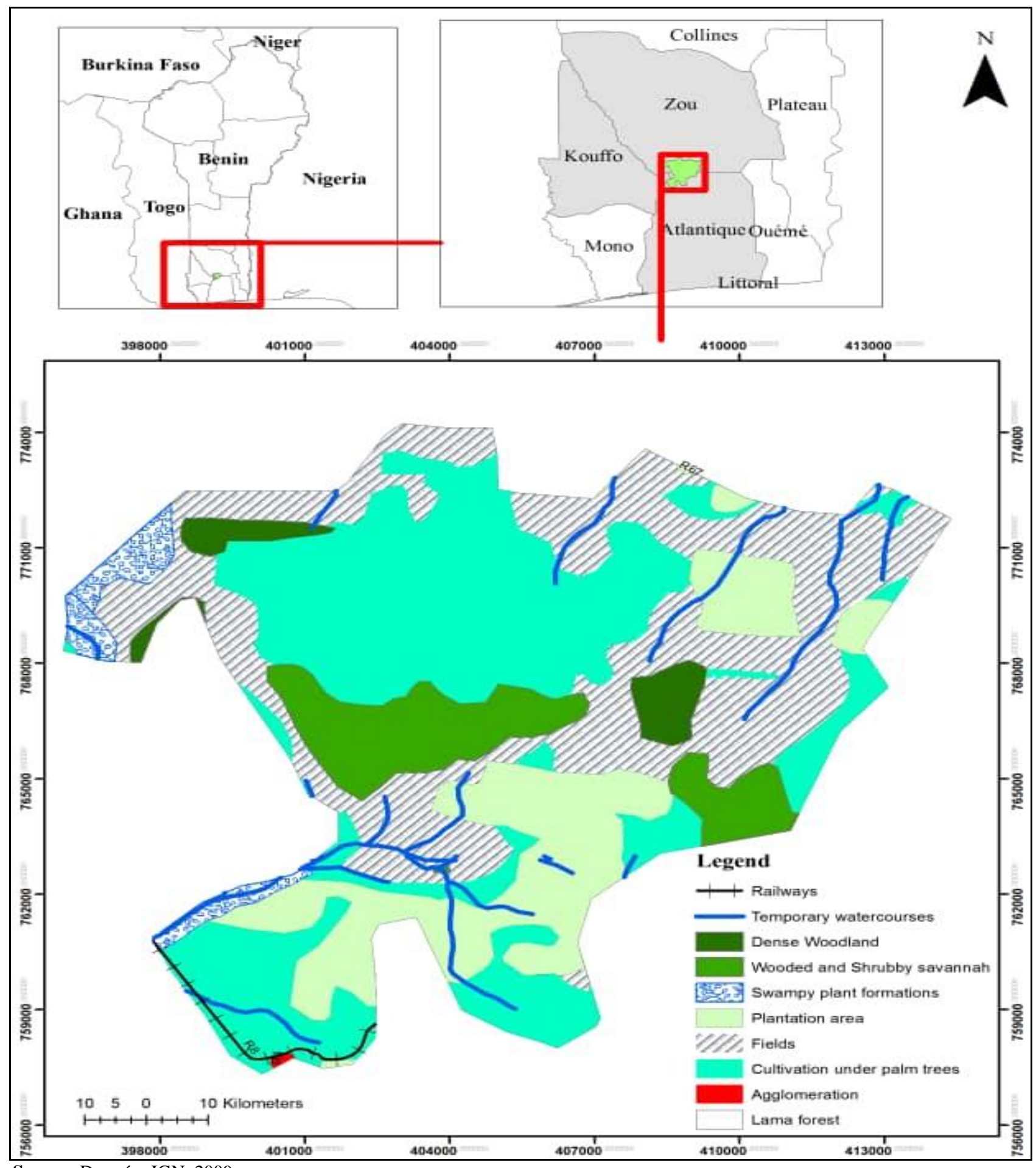

Source: Données IGN, 2009

Fig 1: Lama Forest Reserve in Benin 


\subsection{Wildlife diversity and human resources}

The Lama Forest Reserve is home of mammals, birds, insects, fishes and herps species. According to Emrich et al. ${ }^{[28]}$, it is home to 171 species of birds and 142 of which are known from the Central Core of the forest. The inventory by Emrich et al. ${ }^{[28]}$ reports a total of 19 reptile specimens and 5 amphibians collected and conserved for the whole of the Central Core of the forest. In the ephemeral pools of the Central Nucleus, the presence of Catfish (Clarias gariepinus) and probably endemic Cyprinodontidae ${ }^{[28]}$ is mentionned. With regard to insects, ninety-three (93) species of butterfly have been noted in the Lama Forest Reserve, thirty-eight (38) of which are infested with forest areas, twenty-two (22) with savannahs and 18 are considered ubiquitous. The central core of the Lama Forest Reserve contributes considerably to the specific wealth of termites and lepidoptera in South of Benin. The population around the Lama Forest Reserve is made up of those of the communes of Toffo and Zogbodomey ${ }^{[27]}$. It's estimated at 194,520 inhabitants ${ }^{[29,30]}$ with a growth rate of

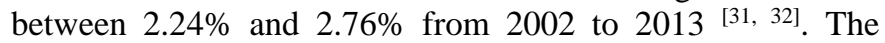
population size projection estimate estimates is at about 224,571 inhabitants in $2018^{[31,32]}$.

\subsection{Data collection}

2.3.1. Identification of hunted species, hunting tools and methods in the Lama Forest Reserve

The snowball method ${ }^{[33-35]}$, used by Nago et al. ${ }^{[36]}$, was used to constitute the field sample of hunters. A total of thirty-one hunters were sampled. The most hunted species were identified on the basis of the frequency of species citation by hunters. The identification of species by the hunters was done by means of a species recognition form containing the name and photo of the species. The surveys were conducted using semi-structured interviews.

The identification of the hunting methods used and the forms of hunting practised in the Lama Forest Reserve was made on the basis of surveys conducted among thirty guards but also among thirty-one hunters, thanks to semi-structured interviews using the snowball method ${ }^{[33,34,35]}$.

\subsubsection{Hunting game species measurement and assessment of the impact of hunting on the conservation of wildlife resources}

As far as surveying is concerned, the various morphometric measurements ${ }^{[37]}$ according to the species were taken using tape measures and scales. The length of the head, the total length of the body, the length of the tail, the length of the wings of the birds and the height at the withers of the ungulates were among other morphometric measurements taken. These species were individuals killed, wounded or captured during huntings, and observed on the roadside or in local game markets.

The sex of the game was identified in order to assess the vulnerability of the females to the sustainability of the species.

\subsection{Data analysis}

2.4.1. Identification of hunted species, hunting tools and methods in the Lama Forest Reserve

The data collected was inserted into the Excel spreadsheet, which allowed to produce graphs showing the numbers and frequencies of the data collected. The function "balloonplot" of the package "gplots" of R software ${ }^{[38]}$ made it possible to make the density table of species according to types of uses and types of habitat. It has been calculated using the Chisquared test to see if the types of use and types of habitat are significant variables. The correspondences analysis was used to see distribution of hunted species according to the types of use and types of habitat.

The Chi-squared test was also applied to see if there is a significant difference between citation frequencies as a function of species (Figure 2). The test was done using the " chisq.test ()" function of R software.

Using the Rstudio tool and the Rcmdr package, the Chisquared test was used to see if there was a significant difference between the respondents' responses according to the forms of hunting use in the Lama Forest Reserve (Figure $5)$, and the frequency of citation in relation to the hunting periods (Figure 7). This test was carried out after filling in the contingency table and applying cross sorting to the 'statistics' tab of the $\mathrm{R}$ commander.

\subsubsection{Hunting game species measurement and assessment} of the impact of hunting on the conservation of wildlife resources

Similarly, the Shannon diversity index and the Piélou diversity index as below were calculated to assess the diversity of species hunted in the Lama Forest Reserve.

- Shannon Wienner diversity index $\mathrm{H}^{\prime}{ }^{[39]}$ used by ChabiBoni et al. ${ }^{[22]}$

$H^{v}=-\sum\left[\left(\frac{n i}{N}\right) * \log _{2}\left(\frac{n i}{N}\right)\right]$, where:

ni: number of individuals of a species $\mathrm{i}$; $\mathrm{N}$ : total number of individuals of all species;

H': Shannon Diversity Index varies from 1 to 5 bits;

$\mathrm{H}^{\prime}$ is high $(\mathrm{H}>3.5)$ : high diversity means that there is a high diversity of species hunted by hunters in the Lama Forest Reserve within the group;

$\mathrm{H}^{\prime}$ is low $(\mathrm{H}<2.6)$ : low diversity means that there is a low diversity of species hunted by hunters in the Lama Forest Reserve.

- Pielou equitability index $\mathrm{E}^{[40]}$ used by Chabi-Boni et al. [22]

It's determined by the following formula:

$E=H^{\prime} / \log _{2} S$

Where $\mathrm{S}$ is the species richness of the species killed or captured by hunters during hunting.

$\mathrm{E}$ is between 0 and 1 . E tends towards 0 when almost all individuals belong to a single species and takes the value 1 when all species have exactly the same overlap.

Concerning assessment of the impact of hunting on the conservation of wildlife resources, the z-test was done to see if there is statistical significance between the proportions of males and females within each species (Figure 9) and within all species combined. It was carried out using the "prop.test ()', function.

\section{Results}

3.1. Identification of the species hunted in the Lama Forest Reserve

The following table 1 presents the different species hunted in the Lama Forest Reserve. Twenty-three species, including mammals, reptiles and birds, are hunted in the Lama Forest Reserve (Table 1). 
Table 1: List of hunted species of Lama Forest Reserve in Southern Benin

\begin{tabular}{|c|c|c|c|}
\hline \multicolumn{2}{|c|}{ Local names } & \multirow{2}{*}{ Scientific names } & \multirow{2}{*}{ Families } \\
\hline Holli & Fon & & \\
\hline Ewou & Ho & Thryonomys swinderianus & Thryonomyidae \\
\hline Ôtou & Zoungbô & Cephalophus monticola & Bovidae \\
\hline Ôtou & Zoungbô & Cephalophus niger & Bovidae \\
\hline- & Tè & Cephalophus maxwelli & Bovidae \\
\hline Awawa & Zounvoun & Dendrohyrax dorsalis & Procaviidae \\
\hline Ikoun & Wassagbé & Xerus erythropus & Sciuridae \\
\hline- & Assoklé & Pternistis bicalcaratus & Phasianidae \\
\hline- & - & Genetta genetta & Viverridae \\
\hline Ôgbanyin & Agbanlin & Tragelaphus scriptus & Bovidae \\
\hline Ehoro & Azoui & Lepus crawshayi & Leporidae \\
\hline Wo koukoui & - & Crossarchus obscurus & Herpestidae \\
\hline Ôgbè & - & Cercopithecus mona & Cercopithecidae \\
\hline Iwô & Lihui & Manis tricuspis & Manidae \\
\hline- & Sonou & Guttera pucherani & Numididae \\
\hline Êlèdè & Gbéglouza & Potamochoerus porcus & Suidae \\
\hline- & Dangbé & Python regius & Pythonidae \\
\hline- & Hon & Python sebae & Pythonidae \\
\hline Awassa & Atchou & Cricetomys gambianus & Nesomyidae \\
\hline Eman & Gbédja & Arvicanthis niloticus & Muridae \\
\hline Ôgbè & Zinvè & Cercopithecus erythrogaster erythrogaster & Cercopithecidae \\
\hline Ochiké & Zin-ayiwè & Chlorocebus aethiops tantalus & Cercopithecidae \\
\hline- & Vê & Varanus niloticus & Varanidae \\
\hline - & Djakpata & Bitis arietans & Viperidae \\
\hline
\end{tabular}

The histograms in figure 2 illustrate the hunted species in the Lama Forest Reserve cited by the respondents. Five species of mammals were hunted as a priority, including Thryonomys swinderianus $(96.77 \%)$, followed respectively by Lepus crawshayi (90.32\%), Cephalophus maxwelli (58.06\%), Xerus erythropus (54.83\%) and Cricetomys gambianus (54.83\%). An inequality was found in the frequency of hunting species in Lama Forest Reserve (X-squared $=147.63, \mathrm{df}=22$, p-value $<2.2 \mathrm{e}-16)$.

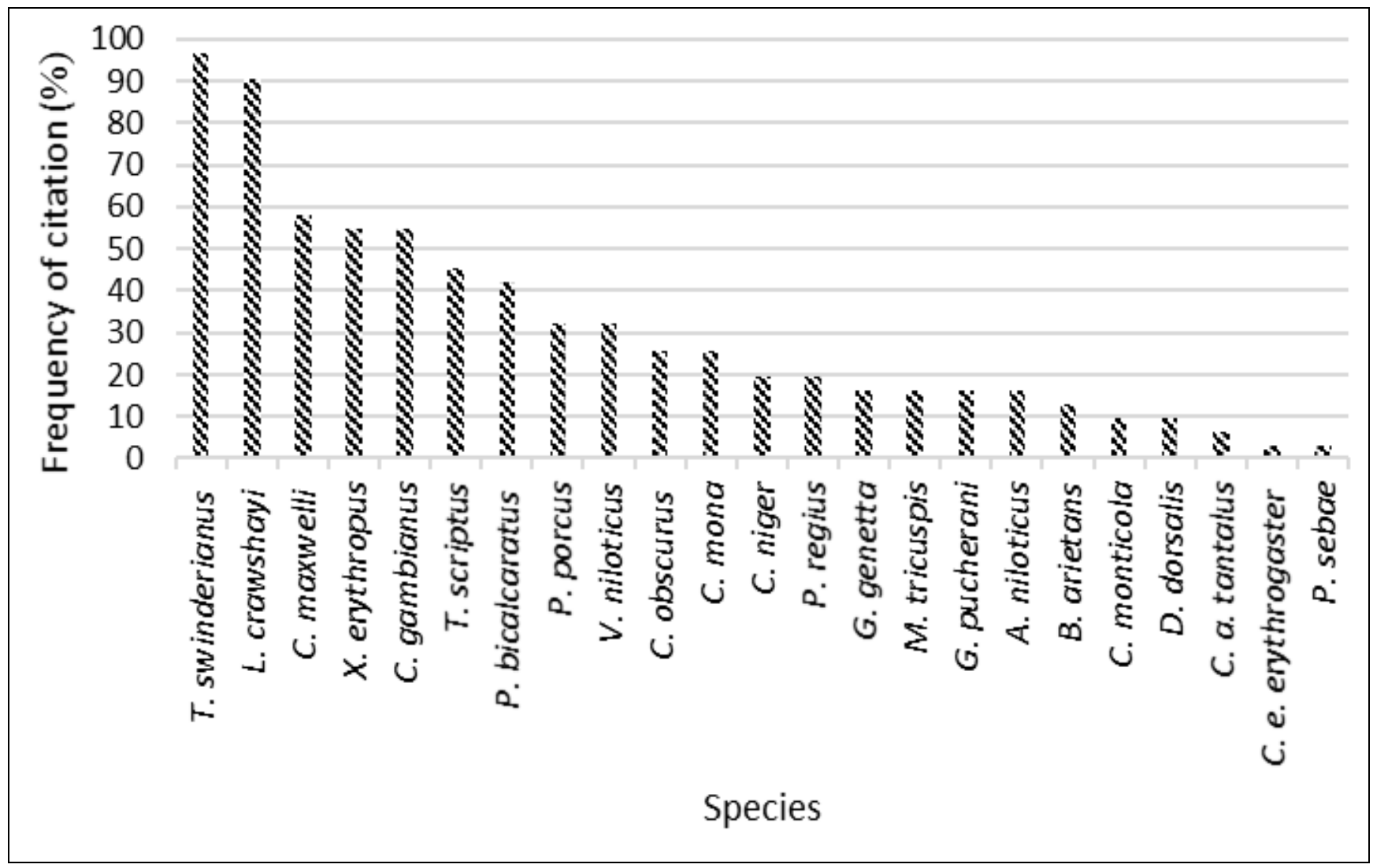

Fig 2: Frequency of citation of the most hunted species according to respondents

Table 2 shows the density of species according to types of uses. The majority of hunted animal species were used for trade (Trade) and meat consumption (Consp), followed by traditional uses (Td_uses) and trophy hunting (H_trph). 
Table 2: Density of species according to types of uses

\begin{tabular}{|c|c|c|c|c|c|}
\hline \multirow[b]{2}{*}{1.} & \multirow[b]{2}{*}{ Thryonomys swinderianus } & \multirow{2}{*}{ Consp } & \multirow{2}{*}{ Trade } & \multirow[t]{2}{*}{$\mathrm{H}$ trph } & \multirow[t]{2}{*}{ Td uses } \\
\hline & & & & & \\
\hline 2. & Cephalophus monticola & $\cdot$ & $\cdot$ & . & \\
\hline 3. & Cephalophus niger & 0 & $\theta$ & - & \\
\hline 4. & Cephalophus maxwelli & 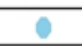 & 0 & 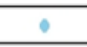 & $\cdot$ \\
\hline 5. & Dendrohyrax dorsalis & 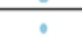 & ? & & \\
\hline 6. & Xerus erythropus & 0 & 0 & & $\theta$ \\
\hline 7. & Pternistis bicalcaratus & e & e & & 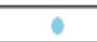 \\
\hline 8. & Genetta genetta & 。 & + & + & . \\
\hline 9. & Tragelaphus scriptus & 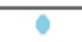 & (0) & 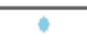 & . \\
\hline 10. & Lepus crawshayi & O & 0 & & \\
\hline $\begin{array}{l}11 . \\
12 .\end{array}$ & $\begin{array}{l}\text { Crossarchus ooscurus } \\
\text { Cercopithecus mona }\end{array}$ & 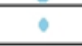 & 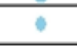 & & $\cdot$ \\
\hline 13. & Manis tricuspis & 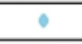 & 4 & 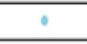 & \\
\hline 14. & Guttera pucherani & $\cdot$ & + & & 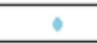 \\
\hline 15. & Potamochoerus porcus & 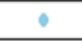 & 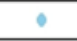 & & \\
\hline 16. & Python regius & 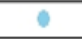 & 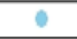 & 4 & \\
\hline 17. & Python sebae & 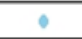 & 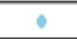 & & + \\
\hline 18. & Cricetomys gambianus & . & . & & \\
\hline 19. & Arvicanthis niloticus & 0 & 0 & & 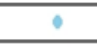 \\
\hline & Cercopithecus erythrogaster & 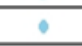 & 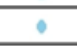 & & \\
\hline & erythrogaster & & . & & + \\
\hline 21. & Chlorocebus aethiops tantalus & . & . & $\cdot$ & \\
\hline 22. & Varanus niloticus & 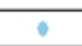 & 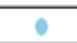 & $\cdot$ & 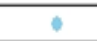 \\
\hline & Bitis arietans & 4 & 4 & & \\
\hline
\end{tabular}

The points in the above figure 3 showed the factor map of hunted species according to types of uses (X-squared = 154.33, df $=66$, $p$-value $<0,0001)$. The differences were statistically significants. More dependency existed between species and consumption and trade uses (Figure 3). The animals were therefore primarily hunted in the Lama Forest Reserve for consumption and trade.

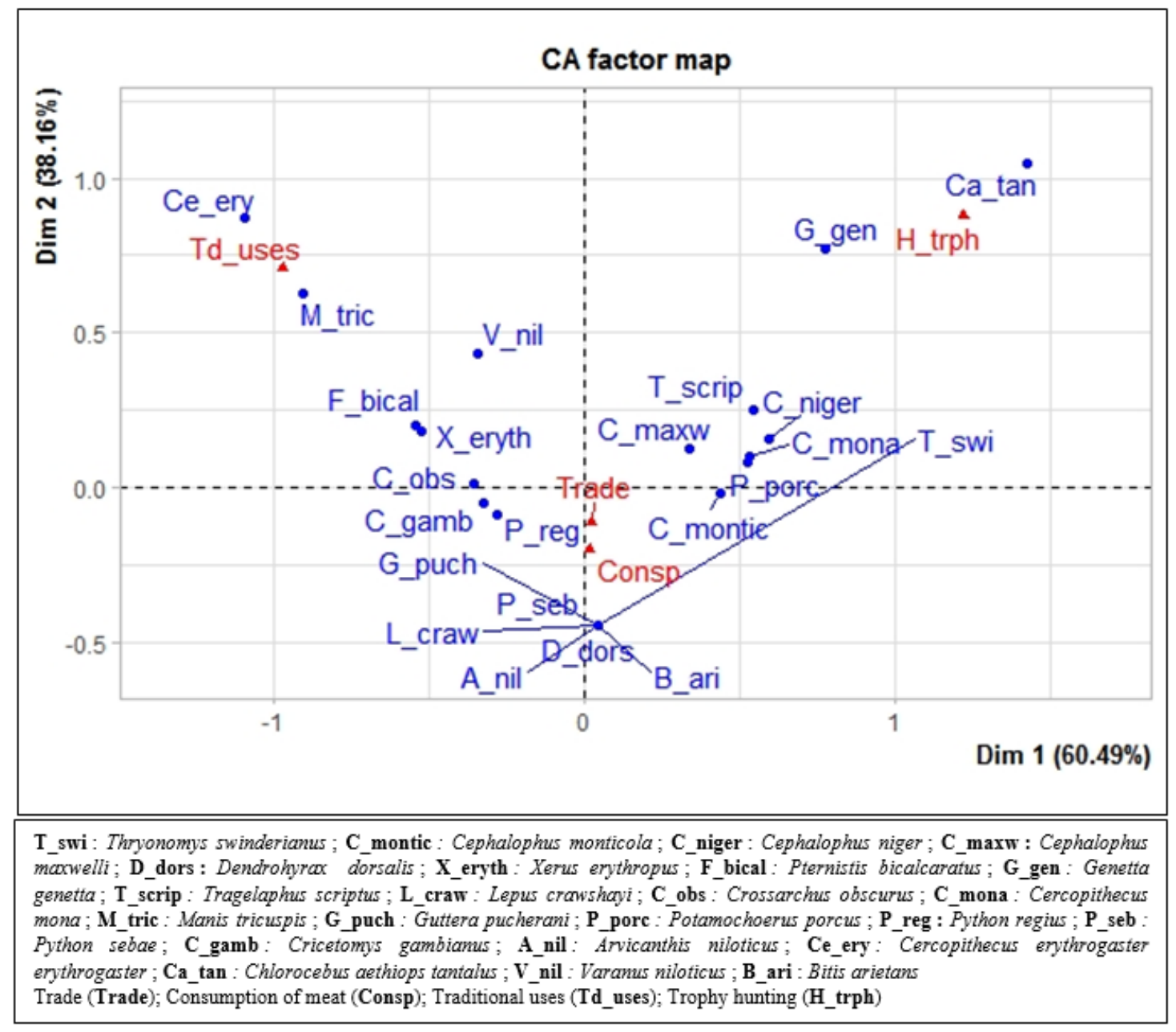

Fig 3: Factor map of hunted species according to types of uses 
In the following table 3 , the density of occurrence of hunting species is presented. The majority of hunted animal species were found within the central core of the forest, followed by plantations surrounding the core zone. Therefore, some species such as Thryonomys swinderianus and Lepus crawshayi were found in large numbers in the fields.

Table 3: Density of species according to types of habitat

\begin{tabular}{|c|c|c|c|c|}
\hline \multirow[b]{2}{*}{1.} & \multirow[b]{2}{*}{ Thryonomys swinderianus } & Field & Planting area & Forest \\
\hline & & 0 & P & P \\
\hline 2. & Cephalophus monticola & & + & $\cdot$ \\
\hline 3. & Cephalophus niger & & $\cdot$ & 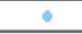 \\
\hline 4. & Cephalophus maxwelli & & 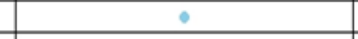 & 웅 \\
\hline 5. & Dendrohyrax dorsalis & & & 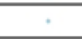 \\
\hline 6. & Xerus erythropus & & & 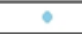 \\
\hline 7. & Pternistis bicalcaratus & & + & $\circ$ \\
\hline 8. & Genetta genetta & 을 & P & $\cdot$ \\
\hline 9. & Tragelaphus scriptus & e & 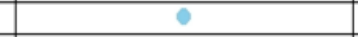 & 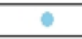 \\
\hline 10. & Lepus crawshayi & & $\circ$ & e \\
\hline 11. & Crossarchus obscurus & 0 & P & + \\
\hline 12. & $\begin{array}{l}\text { Cercopithecus mona } \\
\text { Manis tricuspis }\end{array}$ & & 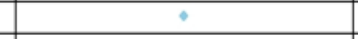 & + \\
\hline 14. & Guttera pucherani & $\cdot$ & $\div$ & $\circ$ \\
\hline 15. & Potamochoerus porcus & & $\cdot$ & $\cdot$ \\
\hline 16. & Python regius & $\cdot$ & & $\cdot$ \\
\hline 17. & Python sebae & & & ㄴ. \\
\hline 18. & Cricetomys gambiamus & $\cdot$ & 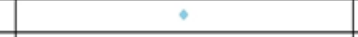 & $\cdot$ \\
\hline 19. & Arvicanthis niloticus & + & & + \\
\hline 20. & Cercopithecus erythrogaster & P & $\div$ & 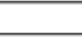 \\
\hline & erythrogaster & 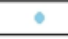 & & \\
\hline 21. & Chlorocebus aethiops tantalus & + & $\cdot$ & $\cdot$ \\
\hline 22. & Varanus niloticus & 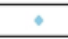 & 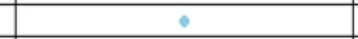 & + \\
\hline 23. & Bitis arietans & 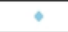 & $\cdot$ & $\cdot$ \\
\hline
\end{tabular}

The points in figure 4 showed the factor map of hunted species according to types of habitat $(\mathrm{X}$-squared $=150.55 \mathrm{df}$ $=44$, p-value < 0,0001). The differences were statistically significants. More dependency was found between species and central core of the forest and planting areas (Figure 4). This confirmed the impact of habitats in the conservation of biological resources, depending on the degree of conservation.

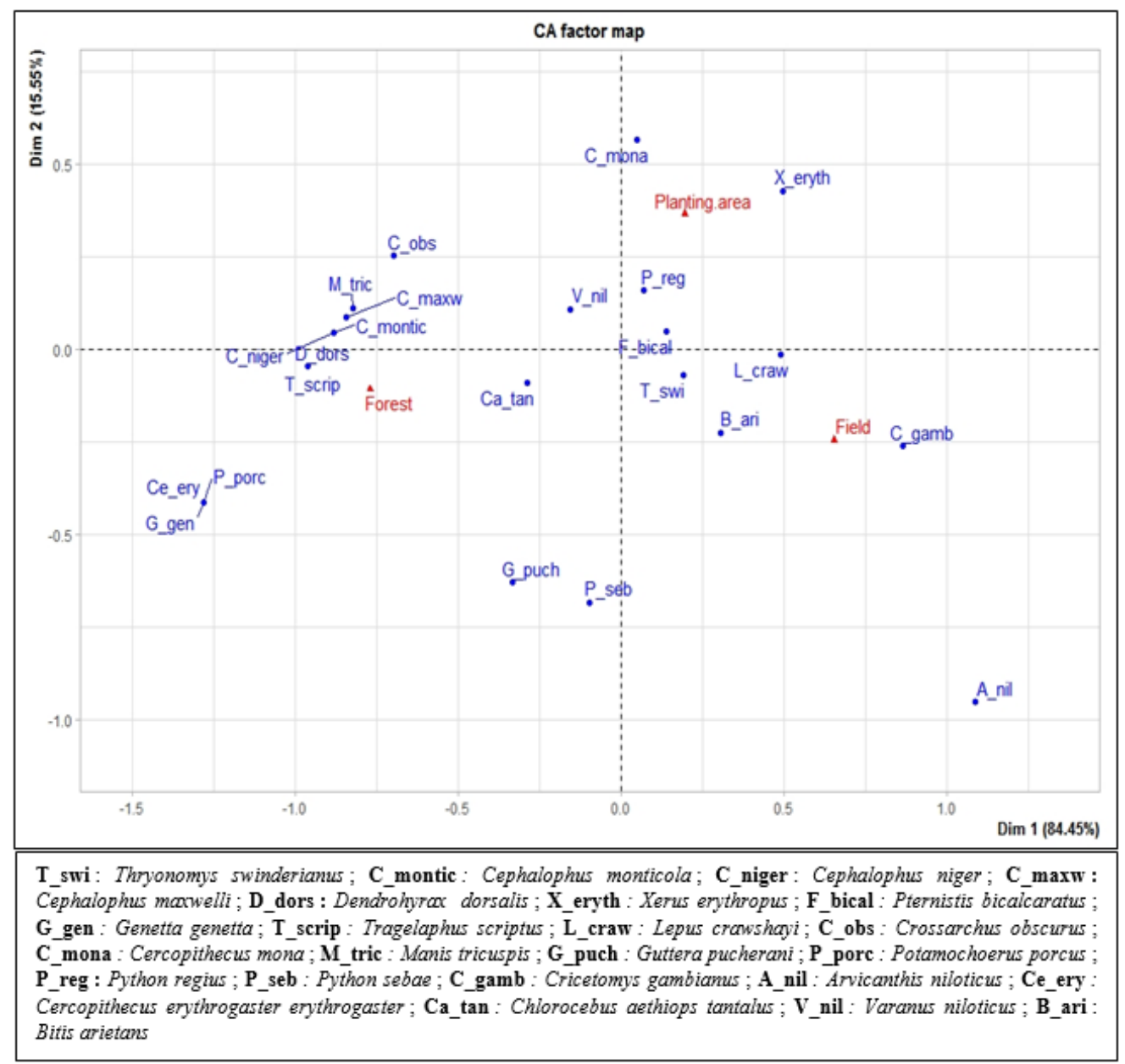

Fig 4: Factor map of hunted species according to types of habitat 
3.2. Identification of hunting tools and methods in the Lama Forest Reserve

Subsistence hunting and commercial hunting were both forms of hunting in the Lama Forest Reserve (Figure 5). Thus, 100\% of the hunters and $83.33 \%$ of the rangers surveyed revealed that the most common form of hunting in the Lama Forest Reserve was commercial hunting. No significant difference existed between subsistence and commercial game hunting in the Lama Forest Reserve (X-squared $=0.0065591$, df $=1$, pvalue $=0.9355)$.

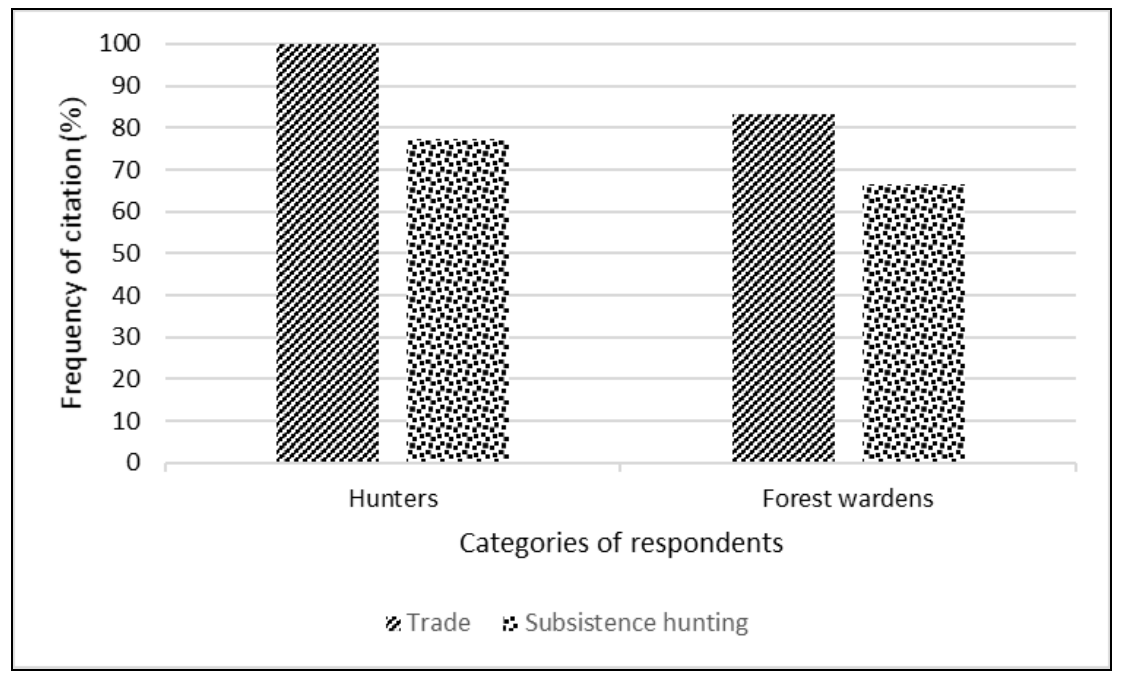

Fig 5: Frequency of citation of forms of hunting by respondents

In order to carry out the hunt, hunters used several means to injure, kill or capture the animals (Figure 6). These means included, among others, metal dog-toothed traps (a), machetes (b), clutch-wire trebuchet (c) and home-made rifles (d).

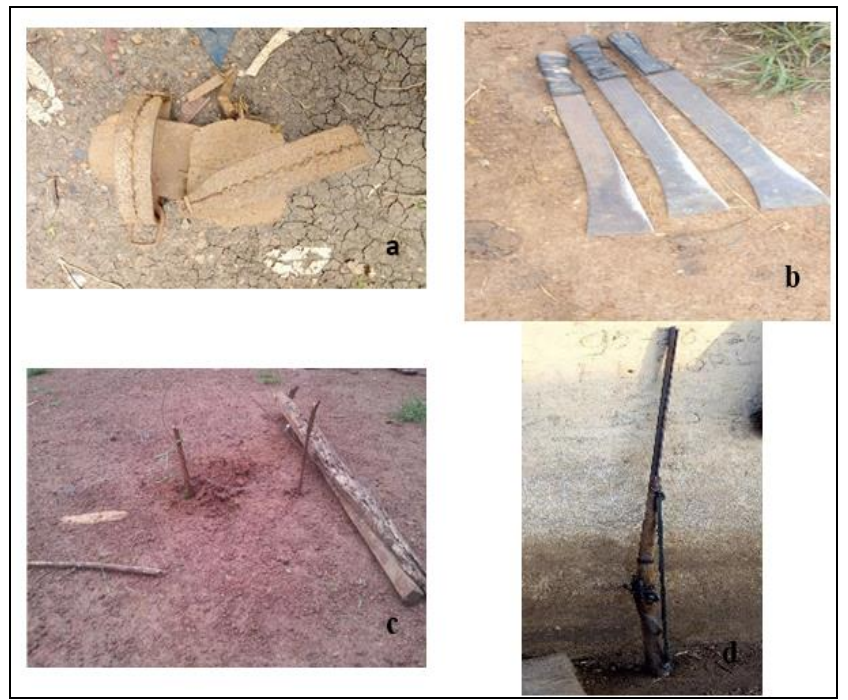

Fig 6: Hunting tools in Lama Forest Reserve

The histogram of figure 7 below illustrates the hunting periods. In the Lama Forest Reserve, hunting took place both in the dry and rainy seasons. Nevertheless, according to $93.33 \%$ of the rangers and $96.77 \%$ of the hunters surveyed, the dry season was the period of intense hunting activities in the Lama Forest Reserve but no significant difference was found for game hunting according to hunting periods (Xsquared $=0.91017, \mathrm{df}=1, \mathrm{p}$-value $=0.3401$ ).

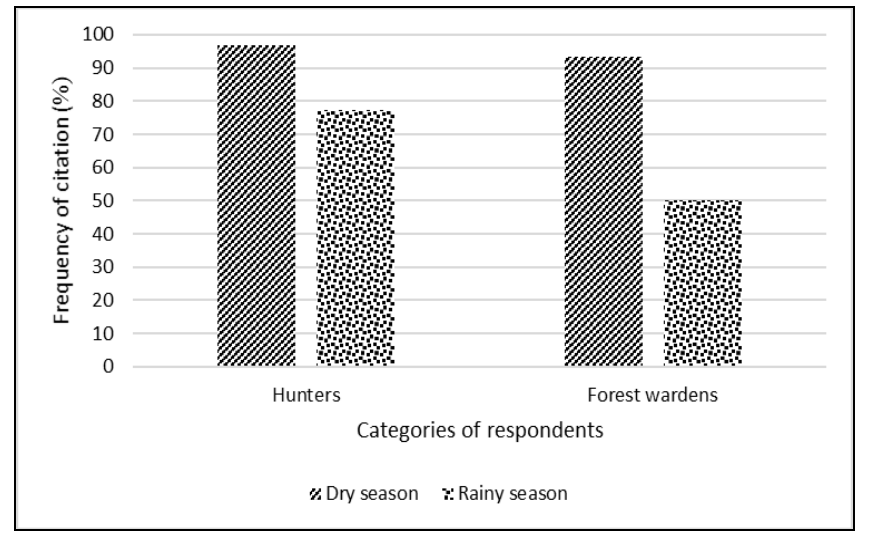

Fig 7: Frequency of citation of hunting periods

Table 4 hereafter presents the hunting methods in the Lama Forest Reserve. According to the investigations, seven hunting methods were distinguished. Several methods were used for game hunting (Table 4). Different methods were used according to the hunting period (dry season and rainy season).

Table 4: Hunting methods in the Lama Forest Reserve according to periods

\begin{tabular}{|c|c|}
\hline Hunting methods & Hunting periods \\
\hline Stalking hunting & Dry season and Rainy season \\
\hline Night hunting & Dry season and Rainy season \\
\hline Hound hunting & Dry season \\
\hline Canvas hunting & Dry season \\
\hline Trapping & Dry season and Rainy season \\
\hline
\end{tabular}


3.3. Morphometric characteristics of hunting game species Figure 8 accounts for the measurements of species in the field. In addition to the frequently hunted species cited by respondents, Naja nigricollis and Cricetomys gambianus were the two other captured species also observed.

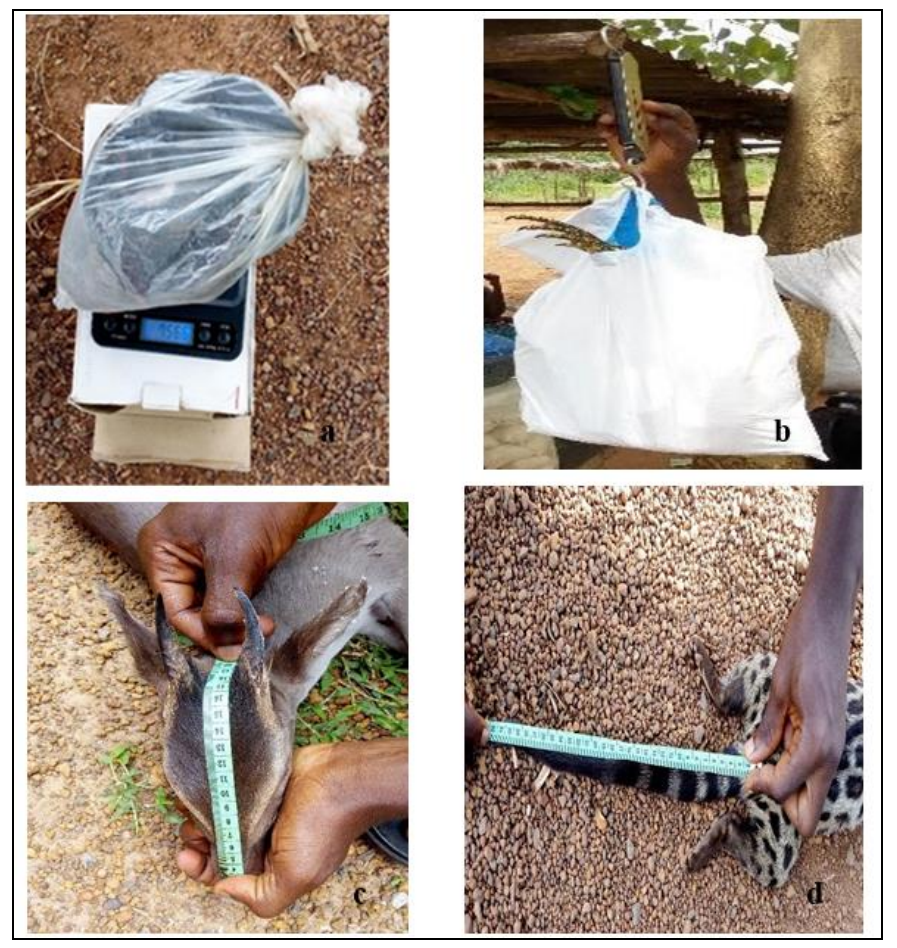

Fig 8: Measurements of hunted game species in Lama Forest Reserve

The measurements of the various parameters considered were recorded in Tables 5, 6 and 7. The parameters measured varied according to the species.

Table 5: Measurement on captured mammals

\begin{tabular}{|c|c|c|c|c|c|}
\hline Species & $\begin{array}{c}\text { Total lenght } \\
\text { LC }(\mathbf{c m})\end{array}$ & $\begin{array}{c}\text { Head's length } \\
\text { LT }(\mathbf{c m})\end{array}$ & Weight $\mathbf{P}(\mathbf{g})$ & $\begin{array}{c}\text { Tail's lenght } \\
\text { LQ }(\mathbf{c m})\end{array}$ & $\begin{array}{c}\text { Height at withers } \\
\text { HG }(\mathbf{c m})\end{array}$ \\
\hline T. swinderianus & $42.46 \pm 8.11$ & $10.23 \pm 1.62$ & $2748.23 \pm 1096.87$ & $14.99 \pm 2$ & - \\
\hline L. crawshayi & $41.76 \pm 2.16$ & $10.40 \pm 0.91$ & $1665.05 \pm 287.50$ & $6.57 \pm 0.84$ & - \\
\hline C. gambianus & $31.53 \pm 3.39$ & $9.26 \pm 1.03$ & $504.11 \pm 390.41$ & $32.76 \pm 2.76$ & - \\
\hline X. erythropus & $29.03 \pm 1.80$ & $8.97 \pm 1.20$ & $661.55 \pm 133.31$ & $25.03 \pm 0.81$ & - \\
\hline C. obscurus & $34.25 \pm 1.76$ & $8.5 \pm 1.41$ & $789.2 \pm 98.85$ & $17.6 \pm 0.84$ & - \\
\hline G. genetta & $40.5 \pm 3.53$ & $9.25 \pm 1.06$ & $829.05 \pm 133.43$ & $34 \pm 2.82$ & - \\
\hline M. tricuspis & 31 & 10 & 503.6 & 35 & - \\
\hline C. maxwelli & 77 & 21 & 6.5 & - & 41 \\
\hline
\end{tabular}

Table 6: Measurement on captured birds

\begin{tabular}{|c|c|c|c|c|c|}
\hline Species & $\begin{array}{c}\text { Total lenght LC } \\
(\mathbf{c m})\end{array}$ & Head's length LT $(\mathbf{c m})$ & $\begin{array}{c}\text { Longueur } \\
\text { de l'aile LA (cm) }\end{array}$ & $\begin{array}{c}\text { Weight P } \\
(\mathbf{g})\end{array}$ & Tail's lenght LQ (cm) \\
\hline P. bicalcaratus & $26.04 \pm 2.66$ & $6.80 \pm 0.53$ & $21.61 \pm 4.02$ & $373.15 \pm 100.77$ & $6.50 \pm 0.80$ \\
\hline G. pucherani & $42 \pm 2$ & $7.67 \pm 0.28$ & $25.67 \pm 2.08$ & $1276 \pm 195.72$ & $16.17 \pm 0.76$ \\
\hline
\end{tabular}

Table 7 : Measurement on captured reptiles

\begin{tabular}{|c|c|c|c|c|}
\hline Species & Total lenght LC $(\mathbf{c m})$ & Head's length LT $(\mathbf{c m})$ & Weight P $(\mathbf{g})$ & Tail's lenght LQ $(\mathbf{c m})$ \\
\hline N. nigricollis & 150 & 7 & 756.6 & 36 \\
\hline V. niloticus & $43.05 \pm 6.76$ & $9.1 \pm 1.94$ & $1637.75 \pm 576.22$ & $49.325 \pm 15.28$ \\
\hline
\end{tabular}

The hunted species diversity index $\mathrm{H}=2.67$ was low $(\mathrm{H}<$ 3.5). A low diversity was found within the species hunted in Lama Forest Reserve. The diversity index E of hunted species $\mathrm{E}=0.75$ tended towards 1 , from which it was able to deduce that most of the species hunted were representative.

3.4. Evaluation of the impact of hunting on the conservation of wildlife resources

The histogram in figure 9 illustrates the proportions of males and females killed according to the species observed. A clear inequality existed in the sex of the species killed. Captured birds observed as well as the ones of Thryonomys swinderianus and Genetta genetta were female.

According to the z-test, no sex difference was noticed between captured individuals for the species Genetta genetta $(\mathrm{p}$-value $=0.3173)$, Crossarchus obscurus $(\mathrm{p}$-value $=1)$, Cephalophus maxwelli $(\mathrm{p}$-value $=1)$, Lepus crawshayi $(\mathrm{p}-$ value $=0.8084)$, Cricetomys gambianus $(\mathrm{p}$-value $=0.4927)$, 
Manis tricuspis $(\mathrm{p}$-value $=1)$, Guttera pucherani $(\mathrm{p}$-value = 1) and Varanus niloticus (p-value $=0.4795$ ).

On the contrary, sex differential hunting existed for three species amongst them Thryonomys swinderianus ( $\mathrm{p}$-value=
0.009322) and Pternistis bicalcaratus (p-value $=0.000818$ ), where females were more hunted than males and, Xerus erythropus $(\mathrm{p}$-value $=0.03565)$, where male individuals were more killed than female.

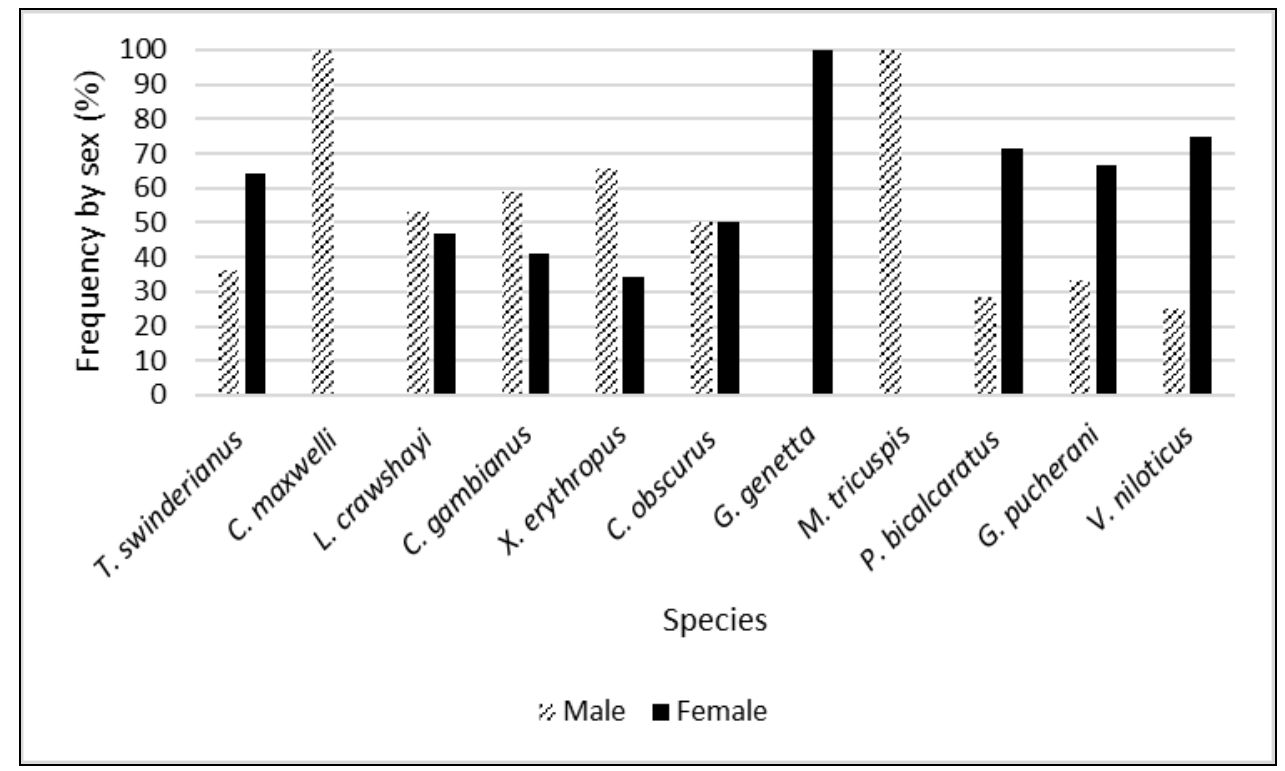

Fig 9: Proportion of species killed by sex

About $55 \%$ of the species killed were females versus $45 \%$ of males and no significant difference existed in the hunting of game species in this reserve according to the sex of the animals $(\mathrm{X}$-squared $=3.2472, \mathrm{df}=1, \mathrm{p}$-value $=0.07155)$.

\section{Discussion}

\subsection{Methodology and data}

This study is a contribution to the ecological monitoring of wildlife. The methodology used is the snowball survey method ${ }^{[33,34,35]}$ used by Nago et al. ${ }^{[36]}$. The investigations are not limited to hunters but also to security guards of the Lama Forest Reserve. This allows for less unquoted information. The statistical analyses have shown that the variables obtained are significants. As far as hunting management is concerned, the method of Robinson and Redford ${ }^{[41]}$ is able to have been tested with the theory of stock recruitment, but requires prior ecological monitoring. The data collected are based not only on surveys but also on observation of the species in the field and their measurements according to the species and the measuring tools.

\subsection{Identification of species hunted in the Lama Forest Reserve}

The results show that twenty-three species are mainly hunted in the Lama Forest Reserve. Similarly, Djagoun et al. [25] showed that around twenty bushmeat species are hunted as a priority. Among these twenty-three species that are hunted, there are five species that are heavily hunted consisting of ungulates and rodents. This confirms the results of Bassett ${ }^{[11]}$, Puit et al. ${ }^{[42]}, \mathrm{Fa}$ and Brown ${ }^{[43]}$, Duonamou et al. ${ }^{[44]}$ and Lattine et al. ${ }^{[45]}$ who state that the bushmeat trade is dominated by mammals. The results of Djagoun et al. [25] revealed the same but to this is added other species such as Philantomba walteri and Atilax paludinosus. This can suggest the rarity of these species two years after the studies of Djagoun et al. ${ }^{[25]}$. In addition to forests, hunted species are found in plantations and fields. The hunting of species such as Thryonomys swinderianus, hares and squirrels is carried out in all three zones but especially in the fields. These results corroborate those found by Codjia and Assogbadjo ${ }^{[2]}$. The results of Chabi-Boni et al. ${ }^{[22]}$, Djagoun et al. ${ }^{[25]}$ and Zangada et al. ${ }^{[46]}$ confirmed that some species, despite anthropogenic pressures, show a preference for more or less anthropised habitats. Some respondents revealed that certain species are captured in large numbers in anthropised environments rather than in protected environments, as revealed by the results of Chabi-Boni et al. ${ }^{[22]}$. This may be due to the fact that the core area is protected and hunters have difficulty hunting there because of surveillance patrols. Hunters capture or kill the species mainly for trade and meat, followed by trophy and magical-religious needs.

\subsection{Identification of hunting tools and methods in the Lama Forest Reserve}

The results show that in the Lama Forest Reserve, hunting is mainly carried out for the bushmeat trade and consumption [47]. Subsistence poaching is mainly of monkey and antelope species ${ }^{[48]}$. Hunters use metal dog-tooth traps, cable traps, machetes and home-made guns as a means of injuring, capturing or killing animals. Trapping and hunting with guns are the most widely practised, according to Fargeot ${ }^{[19]}$. In this study, hunting tools are considered for wildlife as a whole. In the work by Puit et al. ${ }^{[42]}$, the tools were specified, afterwards, according to order, but only with mammals, not with other orders. Hunting is carried out individually or in groups using various methods at night or during the day, in the rainy or dry season depending on the species. Night hunting is gradually being reinforced by the use of LED lights by increasing the frequency and efficiency of hunting, which is becoming a major threat to wildlife ${ }^{[47]}$. The results of the surveys stipulate that hunting takes place more in the dry season than in the rainy season. These results confirm those of ONAB ${ }^{[27]}$.

\subsection{Morphometric characteristics of hunted animals}

Morphometric and body weight measurements such as head 
length, total body length and tail length are taken in general on the eleven species hunted by hunters and specifically wing length in birds and height at withers in ungulates. This study can also have focused on eggs, in oviparous birds, which represent the hope of their survival. In terms of measurements, Ettian et al. ${ }^{[49]}$ in their work, depending on the objectives, had only taken measurements of Thryonomys swinderianus head, tail and hind legs, but also its weight. The parameters measured at the level of the three classes vary according to the species. The average body length of Xerus erythropus is $29.03 \mathrm{~cm}$; the average length of the tail is 25.03 $\mathrm{cm}$ and the average weight is $661.5 \mathrm{~g}$. On the other hand, the work of De Visser et al. ${ }^{[50]}$ showed that the average body and tail length of Xerus erythropus were $25.5 \mathrm{~cm}$ and $21.9 \mathrm{~cm}$ respectively and its average weight was $650 \mathrm{~g}$. The average length of the body and tail of Cricetomys gambianus are $31.53 \mathrm{~cm}$ and $32.76 \mathrm{~cm}$ respectively, while they are $35.2 \mathrm{~cm}$ and $36.1 \mathrm{~cm}$ respectively ${ }^{[50]}$. The average body and tail length of Thryonomys swinderianus are $42.46 \mathrm{~cm}$ and $14.99 \mathrm{~cm}$ respectively while Zangada et al. ${ }^{[46]}$ found that the average body and tail length of the Thryonomys swinderianus are 30 $\mathrm{cm}$ and $20 \mathrm{~cm}$ respectively. Morphometric and body weight measurements show that hunted animals are younger than those hunted some years ago ${ }^{[46,50]}$.

\subsection{Evaluation of the impact of hunting on the conservation of wildlife resources}

In the work of Chabi-Boni et al. ${ }^{[23]}$ and Puit et al. ${ }^{[42]}$, the orders of animals most affected by hunting are presented, and in that of Djagoun et al. ${ }^{[25]}$, the species most affected. This study shows that hunting samples are non-selective with the presence of males and females in the captures. This study goes even further by specifying the vulnerability of species according to gender. The results show that the proportion of female species killed, wounded or captured during hunting is higher than that of male species killed, wounded or captured during hunting. This state of affairs has a negative impact on the reproduction of species as well as on the sustainability and conservation of wildlife resources in the Lama Forest Reserve. The harnessed ibex, duikers, monkeys and bushpigs are all species find mainly in the central core of the forest, but which are economically profitable and therefore more soughtafter by hunters. Investigations by ONAB ${ }^{[27]}$ have already shown a decline in the population of many species in the central core area due to poaching. Studies such as those by Coubéou [51] had already reported once that populations of several species formerly present in the central core had been decimated. In oviparous species, it will also be important to consider the eggs.

\section{Conclusion}

The study shows that hunters hunt species as long as they have a socio-economic interest. Also, no measures restricting the quota or the characteristics of the game to be killed have yet been implemented. It will then be essential to investigate specifically the share of meat consumption in other uses of bushmeat, the protein needs of populations, and then the share of bushmeat in the protein sources of populations in support of the work of Codjia and Assogbadjo ${ }^{[2]}$, with the aim of developing sustainable strategies for species conservation. It will be important for hunters to be officially enlisted and only those species that have already been experimented with will be hunted. Thus, researchers will also carry out experimental ex-situ breeding and reproduction work, as in the case of the grasscutter, which is already quite successful.

\section{Acknowledgements}

The authors sincerely thank the ACUPro project (Appui aux Centres Universitaires Professionnalisant) for the internship grant provided to Johannes Alikpanou. They also like to thank all of Lama Forest Reserve staff, hunting stakeholders surveyed and the managers of the "Office National du Bois" for granting the research permit.

\section{Conflicts of interest}

The authors declare that there are no conflicts of interest regarding this publication.

\section{References}

1. IPGRI. Diversity for development - The new strategy of the International Plant Genetic Resources Institute. Rome, Italy 1999, 69.

2. Codjia JTC, Assogbadjo AE. Faune sauvage mammalienne et al imentation des populations holli et fon de la forêt classée de la Lama (Sud-Bénin). Cahiers Agricultures 2004;13:341-347.

3. Bennett EL, Robinson JG. Hunting of Wildlife in Tropical Forests: implications for Biodiversity and Forest Peoples. The World Bank, Washington 2000, 42.

4. Wilkie DS, Starkey M, Abernethy K, Effa EN, Telfer P, Godoy R. Role of prices and wealth in consumer demand for bushmeat in Gabon central. Conservation Biology. 2005;19:268-247.

5. El Bizri HR, Morcatty TQ, Ferreira JC, Mayor P, Vasconcelos Neto CFA, Valsecchi $\mathrm{J}$ et al. Social and biological correlates of wild meat consumption and trade by rural communities in the Jutai River Basin, central Amazonia. Journal of Ethnobiology 2020;40:183-201.

6. Fa JE, Currie D, Meeuwig J. Bushmeat and food security in the Congo Basin: linkages between wildlife and people's future. Environmental Conservation 2003;30:7178.

7. Nasi R, Brown D, Wilkie D, Bennett E, Tutin C, Van Tol G, Christophersen T. Conservation and Use of Wildlifebased Resources: The Bushmeat Crisis. Secretariat of the Convention on Biological Diversity, Montreal, Canada and Center for International Forestry Research (CIFOR), Indonesia 2008, 50.

8. Mbete RA, Banga-Mboko H, Racey P, MfoukouNtsakala A, Nganga I, Vermeulen C. Household bushmeat consumption in Brazzaville, the Republic of the Congo. Tropical Conservation Science. 2011;4:187202.

9. Chomba C, Senzota R, Chabwela H, Nyirenda V. Lion Hunting and Trophy Quality Records in Zambia for the Period 1967-2000: Will the Trends in Trophy Size Drop as Lion Population Declines? Open Journal of Ecology. 2014;4:182-195.

10. Whitmore TC. Tropical forest disturbance, disappearance, and species loss. In: Tropical Forest Remnants: Ecology, Management, and Conservation of Fragmented Communities, Edn., University of Chicago Press, Laurance WF \& R.O, Bierregaard, Chicago 1997, 3-12.

11. Bassett TJ. Card-carrying hunters, rural poverty, and wildlife decline in northern Côte d'Ivoire. Geographical Journal 2005;171:24-35.

12. Cowlishaw G, Mendelson S, Rowcliffe JM. Evidence for 
post-depletion sustainability in a mature bushmeat market. Journal of Applied Ecology 2005;42:460-468.

13. Fa JE, Seymour S, Dupain J, Amin R, Albrechtsen L, Macdonald D. Getting to grips with the magnitude of exploitation: Bushmeat in the Cross-Sanaga rivers region, Nigeria and Cameroon. Biological Conservation. 2006;129:497-510.

14. Batumike $\mathrm{R}$, Imani $\mathrm{G}$, Urom $\mathrm{C}$, Cuni-Sanchez A. Bushmeat hunting around Lomani National Park, Democratic Republic of the Congo. Oryx. 2020;1-11, https://doi.org/10.1017/S0030605319001017.

15. Moumbock EMA, Ngaba MJY, Dang Ebeng YB. Brève étude le braconnage dans le Parc national de Kom Sanctuaire à gorille de Mengame et sa zone périphérique. International Journal of Innovation and Scientific Research 2020;48:249-257.

16. Richard-Hansen C, Davy D, Longin G, Gaillard L, Renoux F, Grenand $\mathrm{P}$ et al. Les modes de chasse en Guyanne : évolution et impacts sur la faune sauvage. Connaissance et gestion des espèces 2020;327:38-44.

17. Gombeer S, Nebesse C, Musaba P, Ngoy S, Peeters M, Vanderheyden A et al. Exploring the bushmeat market in Brussels, Belgium: a clandestine luxury business. Biodiversity and Conservation 2021;30:55-66.

18. Bowen-Jones E, Pendry S. The threat to primates and other mammals from the bushmeat, and how this threat could be diminished. Oryx 1999;33:233-246.

19. Fargeot C. La chasse commerciale en Afrique centrale : Une activité territoriale de rente. Bois et forêts des tropiques 2005;283:65-80.

20. Suraud JP. Identifier les contraintes pour la conservation des dernières girafes de l'Afrique de l'Ouest : déterminants de la dynamique de la population et patron d'occupation spatiale. Thèse de doctorat, Université Claude Bernard-Lyon I, 2011, 143.

21. INSAE. RGPH4: Que retenir des effectifs de population en 2013, Direction des études démographiques, Bénin, 2015,33 .

22. Chabi-Boni DS, Natta AK, Nago SGA, Mensah GA. Diversité des Espèces de Faunes Chassées et Impact sur la Biodiversité Animale (Nord-Ouest du Bénin). European Scientific Journal 2019;15:263-283.

23. Chabi-Boni DS, Natta AK, Nago SGA, Mensah GA. Circuits de distribution de viandes et trophées braconnés autour de la Réserve de Biosphère de la Pendjari au Bénin. Annales de l'Université de Parakou, Série « Sciences Naturelles et Agronomie 2018;8:23-35.

24. Assogbadjo A, Codjia J, Sinsin B, Ekue M, Mensah GA. Importance of rodents as a human food source in Benin. Belgian Journal of Zoology 2005;135:11- 15.

25. Djagoun CAMS, Sogbohossou EA, Kassa B, Ahouandjinou CB, Akpona HA, Sinsin B. Effectiveness of Protected Areas in Conserving the Highly Hunted Mammal Species as Bushmeat in Southern Benin. The Open Ecology Journal 2018;11:14-24.

26. Cornelis D, Binot A. Synthèse bibliographique du secteur « viandes de brousse » au Gabon. Rapport Cirad-emvt $N^{\circ}$ 04-14, Montpellier 2004, 105.

27. ONAB. Plan directeur d'aménagement et de gestion du noyau central de la forêt classée de la Lama 2011 - 2020. Bénin 2011, 96.

28. Emrich A, Mühlenberg M, Steinhauer-Burkart B, Sturm H. Evaluation écologique intégrée de la forêt naturelle de la Lama en République du Bénin. Rapport de synthèse,
ONAB-KfwGTZ, Cotonou 1999, 74.

29. INSAE. Cahier des villages et quartiers de ville du département du Zou (RGPH-4, 2013), Bénin 2016, 37.

30. INSAE. Cahier des villages et quartiers de ville du département de l'Atlantique (RGPH-4, 2013), Bénin, 2016, 40.

31. INSAE. Synthèse des principaux résultats du RGPH-4 du Zou, Bénin 2016, 4.

32. INSAE. Synthèse des principaux résultats du RGPH-4 de l'Atlantique, Bénin 2016, 4.

33. Heckathorn D. Respondent-Driven Sampling: A new approach to the Study of Hidden Populations. Social Problems 1997;44:174-199.

34. Beaud JP. L'échantillonnage. In Gautier B. (dir), recherche sociale ; de la problématique de la collecte de données, 5 ème édition, les presses de l'Université de Québec 2009, 251-283.

35. Johnston LG, Sabin K. Sampling hard-to-reach populations with respondent driven sampling. Methodological Innovations Online 2010;5:38-48.

36. Nago SGA, Gnohossou P, Sagbo RRS, Bokonon-Ganta E. Perception du changement climatique et stratégies locales d'adaptation dans la pêcherie de la Réserve de Biosphère de la Pendjari, Bénin. Afrique Science 2019;15:114-127.

37. Richard-Hansen C, Vié J-C, Vidal N, Kéravec J. Body measurements on 40 species of mammals from French Guiana. Journal of zoology 1999;247:419-428.

38. Warnes GR, Bolker B, Bonebakker L, Gentleman R, Liaw WHA, Lumley $\mathrm{T}$ et al. Various R Programming Tools for Plotting Data. 2016, 68.

39. Shannon CE. A mathematical theory of communication. The bell system technical journal 1948;27:379-423.

40. Pielou EC. The measurement of diversity in different types of biological collections. Journal of theoretical biology 1966;13:131-144.

41. Robinson JG, Redford KH. Mesuring the sustainability of hunting in Neotropical forests. Oryx 1994;28:249-256.

42. Puit M, Huart A, Leroy P, Nsangou IN. Dynamique de la filière viande de brousse dans la partie continentale du Rio Muni en Guinée équatoriale. Tropicultura 2004;22:204-210.

43. Fa JE, Brown D. Impacts of hunting on mammals in African tropical moist forests: A review and synthesis. Mammal Review 2009;39:231-64.

44. Duonamou L, Konate A, Xu J, Humle T. Temporal evolution of bushmeat traded in High Niger National Park, Guinea, West Africa. Oryx 2020;1-8, https://doi.org/10.1017/S0030605319001443

45. Latinne A, Saputro S, Kalengkongan J, Kowel CL, Gaghiwu L, Ransaleleh TA et al. Characterizing and quantifying the wildlife trade network in Sulawesi, Indonesia, Global Ecology and Conservation 2020;21(e00887):1-18.

46. Zangada N, Masengo C, Bongo G, Ngbolua K. Impact of Human Activities on the Rodent Species Specific Richness in the Masako Reserve Forest in Kisangani, Democratic Republic of the Congo. American Journal of Zoology 2019;2:11-17.

47. Bowler M, Beirne C, Tobler MW, Anderson M, DiPaola A, Fa JE. LED flashlight technology facilitates wild meat extraction across the tropics, Frontiers in Ecology and the Environment 2020;18:489-495.

48. Kassa DB. Techniques de dénombrement des 
mammifères et facteurs déterminant la modélisation de la dynamique de la faune sauvage dans la forêt dense semi décidue de la Lama. Mémoire DESS FSA/ UNB, Abomey-Calavi 2001, 92.

49. Ettian MK, Pomalegni SCB, Aboh BA, Mensah GA. Corrélation entre l'âge, la performance pondérale et les mesures morphométriques linéaires chez les aulacodes engraissés avec des compléments alimentaires. Archivos de Zootecnia 2018;67:500-510.

50. De Visser J, Mensah GP, Codjia JTC, Bokonon-Ganta $\mathrm{AH}$. Guide préliminaire de reconnaissance des rongeurs du Bénin. RéRE, CBDD, VZZ : Rép. du Bénin et Le Royaume des Pays-Bas ; Cotonou 2001, 253.

51. Coubéou PT. Diversité faunique dans les différents biotopes de la forêt classée de la Lama. Mémoire d'Ingénieur Agronome, Faculté des Sciences Agronomiques, Université Nationale du Bénin, AbomeyCalavi (Bénin) 1995, 86. 